\title{
Erzincan ili koyunculuk işletmelerinin yapısal özellikleri ve sorunlarının işletme büyüklüğüne göre incelenmesi
}

\author{
Selçuk ÖZYÜREK ${ }^{1}$, Doğan TÜRKYILMAZ² ${ }^{\text {, Ülkü DAĞDELEN² }}{ }^{2}$ Nurinisa ESENBUĞA² ${ }^{2}$ Mustafa YAPRAK²
}

${ }^{1}$ Erzincan Üniversitesi, Çayırlı Meslek Yüksekokulu, Veterinerlik Bölümü, Çayırlı/ERZINCAN

${ }^{2}$ Atatürk Üniversitesi, Ziraat Fakültesi, Zootekni Bölümü, ERZURUM

Alınıș tarihi: 10 Nisan 2018, Kabul tarihi: 8 Haziran 2018

Sorumlu yazar: Selçuk ÖZYÜREK, e-posta:selcukozyurek@hotmail.com.tr

\section{$\ddot{0} \mathbf{z}$}

$\mathrm{Bu}$ çalışma ile Erzincan ili koyunculuk işletmelerinin yapısal özelliklerinin belirlenmesi ve sorunların tespit edilerek bu sorunlara çözüm önerilerinin sunulması amaçlanmıştır. Çalışma materyalini 2017 yılında Erzincan il ve ilçelerinde koyunculuk işletmesi sahibi 106 kişi ile yüz yüze yapılan anket verileri oluşturmuştur. İşletmeler bir yaş ve üzerindeki hayvan sayılarına göre küçük işletme ( $\leq 100$ baş), orta büyüklükte işletme (101-500 baş) ve büyük işletme ( $\geq 501$ baş) olmak üzere üç gruba ayrılmış ve işletme büyüklüğünün çeşitli faktörlere etkisi incelenmiştir. İşletme başı bir yaş ve üzeri ortalama hayvan varlığı 381,9 baş olarak belirlenmiştir. Yetiștiricilerin \%93'ünün serbest aşım, \%4'ünün elde aşım ve \%3'ünün ise sınıf usulü aşım yaptıkları belirlenmiş ve işletme büyüklüğünün koç katım yöntemi üzerinde istatistiki olarak önemli $(\mathrm{p}<0,05)$ etkisi tespit edilmiştir. Yetiştiricilerin \%29'u doğumlarda ikizlik istememektedir. Büyük işletmelerin tamamının, küçük işletmelerin ise \%81'inin sütü peynir olarak sattığı belirlenmiştir. Küçük işletmelerin \%81'i, büyük işletmelerin ise tamamı Damızlık Koyun Keçi Yetiştiricileri Birliğine üyedir. Sürünün verimini artırmak için, yetiştiricilerin \%82,8'i bilimsel bir ıslah yapmak istediklerini, geriye kalanların ise yapmak istemedikleri belirlenmiştir. Sonuç olarak yetiştiricilerin doğumlarda ikizlik istememeleri, ilk damızlıkta kullanma yaşının büyük olması, koç katımında kendi işletmelerinden koç kullanmaları ve koyunlara koç katımında ek yemleme yapmamaları gibi gerek işletme ekonomisi gerek de ülke ekonomisine zarar veren birtakım yanlış uygulamalar belirlenmiştir.
Anahtar kelimeler: Koyunculuk, süt, koç katımı, yapısal özellik, anket

A research on structural characteristics and problems of sheep breeding according to farmer size in Erzincan

\section{Abstract}

In this study, it was aimed to determine the structural characteristics and problems of Erzincan sheep farms and to propose solutions to these problems. The study was carried out 106 face-to-face surveys with sheep farmers in Erzincan. The farms were divided into three groups according to number of sheep: small farm ( $\leq 100$ head), medium sized farm (101-500 head) and large farm ( $\geq 501$ head). The effect of farm size on various factors was observed. Only $8.6 \%$ of the enterprises are engaged in a different livestock activity except sheep breeding. It was determined that $93 \%$ of the farmers made free mating, 4\% made hand mating and 3\% made class-style mating. The statistical significance was determined $(\mathrm{p}<0.05)$ for mating method on farm size. $29 \%$ of the breeders do not want to be twins in births. It was determined that $81 \%$ of small farm and all large farm were sold as milk cheese. The $81 \%$ of small farm and all large farm are members of the Erzincan Sheep and Goat Breeders Association. In order to increase the efficiency of the sheep, $82.8 \%$ of the farmers wanted to make a scientific improvement and the rest did not want to do it. As a result, incorrect practices that harm both the country and the farm economy have been determined, such as breed- 
ers using their own rams on the mating, not feeding additional sheep on the mating and not wanting to be twins at birth.

Key words: Sheep breeding, milk, mating, structural characteristics, survey

\section{Giriş}

Koyun yetiştiriciliği, dünyada olduğu gibi Türkiye'de de tarımsal üretim içerisinde hem ekonomik açıdan hem de insan sağlığı açısından önemli bir yere sahiptir (Akçapınar 1994; Kaymakçı ve ark., 2009). Tarihsel süreç içerisinde koyunculuk faaliyetinin, Orta Asya'dan Anadolu'ya Türk topluluklarının ekonomik ve sosyal yaşamında önemli bir yer tuttuğu bilinmektedir. Ayrıca ülkemiz meralarının yapısal özellikleri, toplumumuzun devam eden tüketim alışkanlıkları, koyun ürünlerinin sağlıklı beslenmede anlaşılan önemi, az sermaye ile iş olanağı yaratma potansiyeli dikkate alındığında koyun yetiştiriciliğinin sosyoekonomik hayattaki yeri daha iyi anlaşllacaktır (Kaymakçı 2013). Günümüzde özellikle Orta ve Doğu Anadolu Bölgesinde oldukça yaygın olarak koyunculuk faaliyeti yapılmakta ve koyun yetiştiriciliği bu bölgedeki halk için önemli bir gelir kaynağı oluşturmaktadır (Türkyılmaz 2014).

Erzincan, Doğu Anadolu Bölgesinin Kuzey Batı bölümünde yukarı Fırat havzasında yer almaktadır. İlin toplam alanının \%5'ini yaylalar kaplamaktadır. Güneyde Munzur dağlarının uzantıları üzerinde, özellikle Koşan dağı yöresindeki yaylalar, seyrek ve kısa otlarla kaplıdır. Doğuda ise Erzurum-ErzincanBingöl sınırında bulunan Cemal dağlarının Erzincan'da kalan uzantıları üzerinde, verimli yaylalar bulunmaktadır. Bu yaylalardan Çimen, Melan ve Sarıçiçek yaylaları zengin bitki örtüsüne sahiptir (Anonim, 2018). Türkiye İstatistik Kurumu (TUIK, 2018) 2017 yılı verilerine göre toplam 33677636 baş koyun varlığının \%1,24'ünü bulunduran (418 691 baş) Erzincan ilinde ylllık 13444779 ton olan toplam koyun sütü üretiminin \%1,25’i (16 840 ton süt) üretilmektedir. Anlaşılacağı üzere Erzincan ilinin ülkemiz hayvansal üretiminde katkısı yeterli düzeyde değildir ve arttırılması gerekmektedir. Bunu sağlayabilmek için diğer komşu illerden farklı olarak Erzincan'da süt verimi yönünde yetiştirilmekte olan Akkaraman koyunu ve coğrafi işaret belgesine sahip ve hali hazırda üretilmekte olan Erzincan Tulum Peyniri üzerinde durulması gerektiği düşünülmektedir. Tekinşer ve Akar (2017), Erzincan'da yıllık 4-5 bin ton tulum peyniri üretiminin gerçekleștirildiği ve bunun ekonomiye yaklaşık olarak 90-100 milyon liralık katkı sağladığını bildirmişlerdir.

Son yıllarda yapılan küpeleme, destekleme, halk elinde islah projeleri vesilesiyle küçükbaş hayvan yetiștiriciliğinde olumlu bir değișim gözlemlenmektedir. Bu olumlu gelişmelere rağmen kırmızı et alanındaki açı̆̆ın kapanmaması, mera alanlarının verimsizleşmesi, köyden kente göç eden gençler nedeniyle tarımda çalışan nüfusun azalması ve yaş ortalamasının yükselmesi gibi olgular, tarım sektörünü ilerleyen yıllardaki sorunları arasındadır. $\mathrm{Bu}$ bağlamda Erzincan ili koyunculuk işletmelerinin yapısal özelliklerinin belirlenmesini ve sorunların tespitini konu edinen bu çalışma, sorunlara çözüm önerilerinin geliştirilmesini de amaçlamaktadır.

\section{Materyal ve yöntem}

Çalışmanın materyalini 2017 yılında Erzincan ili ve ilçelerindeki koyunculuk işletme sahipleri ile yüz yüze yapılan anket çalışmasından elde edilen veriler oluşturmuştur.

Erzincan Gıda, Tarım ve Hayvancılık Müdürlüğünden alınan verilere göre, 2017 yılı itibariyle koyunculuk yapan işletme sayısı 1250'dir. Basit Tesadüfi Örnekleme Yöntemi ile örnek hacmi belirlenmiştir. Araştırmada kullanılacak işletme sayısı, \%95 güvenilirlik sınırları içerisinde ve \%10 örnekleme hatası ile literatürden yararlanarak aşağıdaki formül kullanarak (Çiçek ve Erkan, 1996; Ceyhan ve ark., 2015) 96 olarak hesaplanmıştır.

$$
n=\frac{N \cdot t^{2} \cdot p \cdot q}{d^{2} \cdot(N-1)+t^{2} \cdot p \cdot q}
$$

n: örnek büyüklüğü

$\mathrm{N}$ : Populasyon büyüklüğü (1 250)

$t$ \% \%95 güven aralığında $t$ cetvel değeri $(1,96)$

p: 0,5 (\%50 görülme sıklı̆̆l)

q: 0,5 (\%50 görülmeme sıklı̆̆ı)

d: Örnekleme hatası $(0,10)$

Erzincan merkez ve ilçelerdeki küçükbaş işletme sayısı ile doğru orantılı olarak, Erzincan il merkezine bağlı köylerden 7, Üzümlü 6, Kemaliye 6, Refahiye 9, Kemah 19, İliç 19, Tercan 20 ve Çayırlı 20 olmak üzere toplam 106 işletme üzerinde çalışma yapılmıştir.

Microsoft Excel 2013 programına aktarılan verilerde işletmeler bir yaş ve üzerindeki hayvan sayılarına göre küçük işletme $(\leq 100)$, orta büyüklükte işletme (101-500) ve büyük işletme ( $\geq 501$ ) olmak üzere üç gruba ayrılmıştır. 
İşletme büyüklüğü kesikli bağımsız değişkeninin, sürü yönetimi, verim özellikleri, pazarlama, hayvan besleme, sağlık uygulamaları, örgütlenme ve çeşitli yetiştiricilik sorunlarına etkisini incelemek için uygun bir istatistiksel paket program ile Ki-kare analizi yapılmıștır (Yazıcıoğlu ve Erdoğan, 2004).

\section{Bulgular}

\section{Genel özellikler}

Çalışmaya katılan yetiştiricilerin yaş ortalaması 41,6'dır. Yetiştiricilerin \%4,9'u okuryazar, \%63,1'i ilkokul, \%27,2'si lise, \%4,8'i ise yüksekokul-lisans mezunudur. İşletme başı, bir yaș ve üzeri ortalama hayvan varlığı 381,9 baștır. \%7,4'ü Morkaraman ve \%92,6'sı Akkaraman ırkı koyun yetiștiriciliği yapan işletmelerin yalnızca \%8,6'sı koyun yetiștiriciliğinin haricinde farklı bir hayvancılı faaliyeti ile uğraşmaktadır.

\section{Sürü yönetimi}

Üreticilerin \%93'ünün serbest aşım, \%4'ünün elde aşım ve \%3'ünün ise sınıf usulü aşım yaptıkları belirlenmiştir. İşletme büyüklüğünün koç katım yöntemi üzerine istatistiki olarak önemli $(\mathrm{p}<0,05)$ etkisi olduğu saptanmıștır. Büyük işletmelerin tamamı ser- best aşım yaparken, küçük işletmelerinde \%14,3’ü elde aşım yapmaktadır. Orta büyüklükteki işletmelerin ise \%6'sının sınıf usulü aşım yaptığı belirlenmiştir.

"Koç katımında kendi ișletmenizde yetiștirdiğiniz koçunuzu mu kullanıyorsunuz?" sorusuna yetiştiricilerin \%91'i evet ve \%9'u ise hayır cevabını vermiştir. İşletme büyüklüğü ile katımında kullanılan koçun temin edildiği yer arasında önemli ilişki belirlenmiştir. Buna göre küçük ișletmelerin $\% 23,8^{\prime}$ i, büyük ișletmelerin \%10,3'ü ve orta büyüklükteki ișletmelerin ise sadece \%2'si damızlık koçu işletme dışından temin etmektedir.

Yetiştiricilerin \%71'i doğumlarda ikizlik isterken, $\% 29^{\prime} u$ ise istememektedir. Küçük ișletmelerin $\% 14,3$ 'ü, orta büyüklükteki ișletmelerin $\% 28$ 'i ve büyük işletmelerin ise \%41,4'ü doğumlarda ikizlik istememektedir.

İşletmelerde koç katımı ortalama 79,2 gün sürmektedir. Yetiştiricilerin sadece \%15'i bir yaşındaki dişi kuzuların koç katımında kullanılmasını istemektedir. İşletmelerin sadece \%2,9'u makineli sağım yapmakta, geri kalan işletmeler ise elle sağım yapmaktadır.

Çizelge 1. Erzincan ili koyunculuk işletmelerinin sürü yönetimi uygulamaları

\begin{tabular}{|c|c|c|c|c|c|c|c|c|}
\hline \multirow[b]{2}{*}{ Özellik } & & & \multicolumn{3}{|c|}{ Gruplar } & \multirow[b]{2}{*}{ Ortalama } & \multirow[b]{2}{*}{ Ki-kare } & \multirow[b]{2}{*}{$\mathrm{P}$} \\
\hline & & & $\begin{array}{l}\leq 100 \\
\text { baș }\end{array}$ & $\begin{array}{l}101-500 \\
\text { baș }\end{array}$ & $\geq 501$ baş & & & \\
\hline \multirow{6}{*}{$\begin{array}{l}\text { Koç katımında hangi yöntemi uygu- } \\
\text { luyorsunuz }\end{array}$} & Serbest așım & $\mathrm{n}$ & 18 & 46 & 29 & 93 & \multirow{6}{*}{10.492} & .033 \\
\hline & & $\%$ & 85.7 & 92.0 & 100.0 & 93.0 & & \\
\hline & Sınıf usulü așım & $\mathrm{n}$ & - & 3 & - & 3 & & \\
\hline & & $\%$ & - & 6.0 & - & 3.0 & & \\
\hline & Elde aşım & $\mathrm{n}$ & 3 & 1 & - & 4 & & \\
\hline & & $\%$ & 14.3 & 2.0 & - & 4.0 & & \\
\hline \multirow{4}{*}{$\begin{array}{l}\text { Koç katımında kendi koçunuzu mu } \\
\text { kullanıyorsunuz? }\end{array}$} & Evet & $\mathrm{n}$ & 16 & 49 & 26 & 91 & \multirow{4}{*}{8.679} & .013 \\
\hline & & $\%$ & 76.2 & 98.0 & 89.7 & 91.0 & & \\
\hline & Hayır & $\mathrm{n}$ & 5 & 1 & 3 & 9 & & \\
\hline & & $\%$ & 23.8 & 2.0 & 10.3 & 9.0 & & \\
\hline \multirow{4}{*}{ Doğumlarda ikizlik ister misiniz? } & Evet & $\mathrm{n}$ & 18 & 36 & 17 & 71 & \multirow{4}{*}{4.391} & .111 \\
\hline & & $\%$ & 85.7 & 72.0 & 58.6 & 71.0 & & \\
\hline & Hayır & $\mathrm{n}$ & 3 & 14 & 12 & 29 & & \\
\hline & & $\%$ & 14.3 & 28.0 & 41.4 & 29.0 & & \\
\hline
\end{tabular}

Çizelge 2.'de yetiştiricilerin işletmelerine ait bazı verim özellikleri ve süt pazarlama yöntemleri verilmiștir. Yetiștiricilerin \%49’u 300-600g, \%23'ü 0$300 \mathrm{~g}, \% 16$ 'sı 600-1000g ve \%12'si 1000g'dan daha fazla koyun başına günlük ortalama süt elde ettiklerini bildirmiştir. İşletme büyüklügü ile günlük koyun başına ortalama süt verimi arasında önemli bir ilişki belirlenememiștir. Üreticilerin \%95'i ürettikleri sütü peynir, \%4'ü tereyağı ve \%1'i ise çiğ süt olarak sattıklarını bildirmişlerdir. İşletme büyüklüğü ile üreti- len sütün değerlendirilme şekli arasında anlamlı bir ilişki $(p<0,01)$ bulunmuştur. Büyük işletmelerin tamamı, küçük işletmelerin ise \%81'i sütü peynir olarak satmaktadırlar.

Üreticilerin \%70'i hayvanlarına vitamin ve mineral katkısı verirken $\% 30 \mathrm{u}$ vitamin ve mineral katkısı kullanmadığını bildirmiştir. İşletme büyüklüğü ile vitamin ve mineral katkısı kullanma arasında önemli bir ilişki bulunmamıştır. İşletmelerin \%84'ü kaba ve kesif yemi birlikte verirken \%16'sı kaba ve kesif 
yemi ayrı ayrı vermektedir (Çizelge 3.). Koç katım döneminde yetiştiricilerin \%91'i dişi hayvanlara ek yemleme uygulaması yapmazken sadece \%9'u ek yemleme uygulaması yapmaktadır. Ek yemleme, en fazla orta büyüklükteki (\%12) işletmeler tarafından yapılmaktadır. Fakat işletme büyüklüğü ile ek yem- leme yapılması arasında istatistiki bir fark bulunamamıştır. Yetiştiricilerin \%11,5'i yonca kuru otu, \%18,0'i çayır kuru otu, \%67,2'i saman ve \%3,3'ü mısır silajını kaba yem kaynağı olarak kullanırken, \%88,1'i arpa, \%9,1'i fabrika yemi, \%2,7'si de kepeği kesif yem kaynağı olarak kullanmaktadır.

Çizelge 2. Erzincan ili koyunculuk işletmelerinin verim özellikleri ve pazarlama durumları

\begin{tabular}{|c|c|c|c|c|c|c|c|c|}
\hline \multirow[b]{2}{*}{ Özellik } & & & \multicolumn{3}{|c|}{ Gruplar } & \multirow[b]{2}{*}{ Ortalama } & \multirow[b]{2}{*}{ Ki-kare } & \multirow[b]{2}{*}{$\mathrm{P}$} \\
\hline & & & $\begin{array}{l}\leq 100 \\
\text { baş }\end{array}$ & $\begin{array}{l}101-500 \\
\text { baş }\end{array}$ & $\geq 501$ baş & & & \\
\hline \multirow{8}{*}{$\begin{array}{c}\text { Sağımda günlük ortalama kaç gram } \\
\text { süt alıyorsunuz? (mg) }\end{array}$} & $0-300$ & $\mathrm{n}$ & 4 & 13 & 6 & 23 & \multirow{8}{*}{4.410} & .621 \\
\hline & & $\%$ & 19.0 & 26.0 & 20.7 & 23.0 & & \\
\hline & $300-600$ & $\mathrm{n}$ & 8 & 24 & 17 & 49 & & \\
\hline & & $\%$ & 38.1 & 48.0 & 58.6 & 49.0 & & \\
\hline & $600-1000$ & $\mathrm{n}$ & 6 & 7 & 3 & 16 & & \\
\hline & & $\%$ & 28.6 & 14.0 & 10.3 & 16.0 & & \\
\hline & $>1000$ & $\mathrm{n}$ & 3 & 6 & 3 & 12 & & \\
\hline & & $\%$ & 14.3 & 12.0 & 10.3 & 12.0 & & \\
\hline \multirow{6}{*}{$\begin{array}{l}\text { Ürettiğiniz sütü hangi ürün olarak } \\
\text { satıyorsunuz? }\end{array}$} & $\begin{array}{l}\text { Süt olarak } \\
\text { satıyoruz }\end{array}$ & $\mathrm{n}$ & - & 1 & - & 1 & \multirow{6}{*}{16.608} & \multirow[t]{6}{*}{.002} \\
\hline & & $\%$ & - & 2.0 & - & 1.0 & & \\
\hline & Peynir olarak & $\mathrm{n}$ & 17 & 49 & 29 & 95 & & \\
\hline & \multirow{3}{*}{$\begin{array}{l}\text { Tereyağı olarak } \\
\text { satıyoruz }\end{array}$} & $\%$ & 81.0 & 98.0 & 100.0 & 95.0 & & \\
\hline & & $\mathrm{n}$ & 4 & - & - & 4 & & \\
\hline & & $\%$ & 19.0 & - & - & 4.0 & & \\
\hline
\end{tabular}

Çizelge 3. Erzincan ili koyunculuk işletmelerinin hayvan besleme konusundaki durumları

\begin{tabular}{|c|c|c|c|c|c|c|c|c|}
\hline \multirow[b]{2}{*}{ Özellik } & & & \multicolumn{3}{|c|}{ Gruplar } & \multirow[b]{2}{*}{ Ortalama } & \multirow[b]{2}{*}{ Ki-kare } & \multirow[b]{2}{*}{$\mathrm{P}$} \\
\hline & & & $\begin{array}{c}\leq 100 \\
\text { baș }\end{array}$ & $\begin{array}{c}101-500 \\
\text { baș }\end{array}$ & $\geq 501$ baş & & & \\
\hline \multirow{4}{*}{$\begin{array}{l}\text { Vitamin ve mineral ilavesi } \\
\text { yapıyor musunuz? }\end{array}$} & Evet & $\mathrm{n}$ & 14 & 34 & 22 & 70 & \multirow{4}{*}{0.681} & .711 \\
\hline & \multirow{3}{*}{ Hayır } & $\%$ & 66.7 & 68.0 & 75.9 & 70.0 & & \\
\hline & & $\mathrm{n}$ & 7 & 16 & 7 & 30 & & \\
\hline & & $\%$ & 33.3 & 32.0 & 24.1 & 30.0 & & \\
\hline \multirow{4}{*}{ Yemliklerde } & $\begin{array}{c}\text { Kesif ve kaba yem ayrı } \\
\text { ayrı yemliklerde }\end{array}$ & $\mathrm{n}$ & 3 & 11 & 2 & 16 & \multirow{4}{*}{3.173} & .205 \\
\hline & & $\%$ & 14.3 & 22.0 & 6.9 & 16.0 & & \\
\hline & $\begin{array}{c}\text { Kesif ve kaba yem aynı } \\
\text { yemlikte }\end{array}$ & $\mathrm{n}$ & 18 & 39 & 27 & 84 & & \\
\hline & & $\%$ & 85.7 & 78.0 & 93.1 & 84.0 & & \\
\hline \multirow{4}{*}{$\begin{array}{l}\text { Koç katım döneminde koyun- } \\
\text { lara meraya ek yemleme } \\
\text { yapıyor musunuz? }\end{array}$} & Evet & $\mathrm{n}$ & 2 & 6 & 1 & 9 & \multirow{4}{*}{1.648} & \multirow[t]{4}{*}{.439} \\
\hline & & $\%$ & 9.5 & 12.0 & 3.4 & 9.0 & & \\
\hline & Hayır & $\mathrm{n}$ & 19 & 44 & 28 & 91 & & \\
\hline & & $\%$ & 90.5 & 88.0 & 96.6 & 91.0 & & \\
\hline
\end{tabular}

Yetiştiricilerin hayvan sağlı̆̆ uygulamalarına ait sonuçlar Çizelge 4.'de verilmiştir. Yetiştiricilerin \%93'ü hayvanlarına düzenli aşı uygulaması yaparken, sadece \%7'si düzenli bir aşı takvimi uygulamadığını belirtmiştir. İşletme büyüklüğü ile düzenli aşı uygulaması arasında anlamlı bir ilişki bulunmamıştir.

Yetiştiricilerin \%46'sı işletmesinde düzenli veteriner kontrolü yaptırırken, \%54'ü ise düzenli veteriner kontrolü yaptırmamaktadır. En fazla orta büyüklükteki işletmeler (\%54) düzenli veterinerlik hizmeti alırken, büyük ișletmelerin sadece \%27,6'sı düzenli veteriner hizmeti aldı̆̆ını bildirmiş fakat bu ilişki anlamlı bulunmamıștır.

Yetiştiricilerin \%93'ü iç ve dış paraziter mücadele yaptığını bildirirken sadece \%7'si iç ve dış paraziter mücadele yapmadığını bildirmiştir. İşletme büyüklüğü ile iç ve dış paraziter mücadele yapma arasında anlamlı ilişki $(\mathrm{p}<0,01)$ bulunmuştur. Küçük işletmelerin \%76,2'si, orta büyüklükteki işletmelerin \%96'sı ve büyük işletmelerin ise tamamı iç ve dış paraziter mücadele yaptığını bildirmiştir. İşletme büyüklüğü 
arttıkça iç ve dış parazit mücadele yapan işletme oranının da arttığı belirlenmiştir.

İşletmelerin \%85,5'i hayvanlara aşı uygulamasını kendileri yapmakta ve sadece \%25'i doğumdan sonra kuzuların göbek kordonu temizliği yapmaktadır. İşletmelerde en fazla görülen hastalıkların enterotoksemi $(\% 36,0)$, solunum yolu enfeksiyonları $(\% 24,0)$ ve dışparaziter hastalıklar $(\% 13,0)$ olduğu belirlenmiștir.

Yetiştiricilerin \%92,9’u Damızlık Koyun Keçi Yetiştiricileri Birliğine (DKKYB), \% 7,1'i ise Tarım Kredi Kooperatifine üye olduğunu bildirmiştir (Çizelge 5.). İşletme büyüklüğü ile üye olunan yetiştirici örgütü arasında anlamlı ilişki bulunmuştur. Küçük işletmelerin \%81'i DKKYB'ye ve \%19'u Tarım Kredi Koope- ratifine; büyük işletmelerin ise tamamı sadece DKKYB'ye üyedir.

Sürünün verimini artırmak için, yetiştiricilerin $\% 82,8$ 'i bilimsel bir islah yapmak istediklerini, geriye kalanların ise yapmak istemedikleri belirlenmiştir. İşletme büyüklüğü ile ıslah yapma isteği arasında anlamlı bir ilişki bulunmamıştır.

İşletmelerin \%65,7'si yaptıkları işten memnunken, \%34,3'ü yaptıkları işten memnun değillerdir. Küçük, orta büyüklükte ve büyük işletmelerde yaptıkları işten memnuniyet oranı sirası ile \%76,2, \%65,3 ve \%58,6 oranlarında bulunmuştur. İşletme büyüklüğü arttıkça yapılan işten memnuniyetsizlik oranı atmaktadir.

Çizelge 4. Erzincan ili koyunculuk işletmelerinin sağlık uygulamaları

\begin{tabular}{|c|c|c|c|c|c|c|c|c|}
\hline \multirow[b]{2}{*}{ Özellik } & & & \multicolumn{3}{|c|}{ Gruplar } & \multirow[b]{2}{*}{ Ortalama } & \multirow[b]{2}{*}{ Ki-kare } & \multirow[b]{2}{*}{$\mathrm{P}$} \\
\hline & & & $\begin{array}{l}\leq 100 \\
\text { baș }\end{array}$ & $\begin{array}{l}101-500 \\
\text { baș }\end{array}$ & $\geq 501$ baş & & & \\
\hline \multirow{4}{*}{$\begin{array}{l}\text { Hayvanlarınıza düzenli aşı yaptırıyor } \\
\text { musunuz? }\end{array}$} & Evet & $\mathbf{n}$ & 20 & 48 & 25 & 93 & \multirow{4}{*}{2.908} & .234 \\
\hline & & $\%$ & 95.2 & 96.0 & 86.2 & 93.0 & & \\
\hline & Hayır & $\mathbf{n}$ & 1 & 2 & 4 & 7 & & \\
\hline & & $\%$ & 4.8 & 4.0 & 13.8 & 7.0 & & \\
\hline \multirow{4}{*}{$\begin{array}{l}\text { Düzenli veteriner kontrolü yapılıyor } \\
\text { mu? }\end{array}$} & Evet & $\mathbf{n}$ & 11 & 27 & 8 & 46 & \multirow{4}{*}{5.591} & .061 \\
\hline & & $\%$ & 52.4 & 54.0 & 27.6 & 46.0 & & \\
\hline & Hayır & n & 10 & 23 & 21 & 54 & & \\
\hline & & $\%$ & 47.6 & 46.0 & 72.4 & 54.0 & & \\
\hline \multirow{4}{*}{$\begin{array}{c}\text { İç ve dış paraziter mücadele yapıyor } \\
\text { musunuz? }\end{array}$} & Evet & $\mathbf{n}$ & 16 & 48 & 29 & 93 & \multirow{4}{*}{11.989} & .002 \\
\hline & & $\%$ & 76.2 & 96.0 & 100.0 & 93.0 & & \\
\hline & Hayır & $\mathbf{n}$ & 5 & 2 & 0 & 7 & & \\
\hline & & $\%$ & 23.8 & 4.0 & .0 & 7.0 & & \\
\hline
\end{tabular}

Çizelge 5. Erzincan ili koyunculuk işletmelerinin örgütlenme ve çeşitli yetiştiricilik sorunları

\begin{tabular}{|c|c|c|c|c|c|c|c|c|}
\hline \multirow[b]{2}{*}{ Özellik } & & & \multicolumn{3}{|c|}{ Gruplar } & \multirow[b]{2}{*}{ Ortalama } & \multirow[b]{2}{*}{ Ki-kare } & \multirow[b]{2}{*}{$\mathrm{P}$} \\
\hline & & & $\begin{array}{l}\leq 100 \\
\text { baş }\end{array}$ & $\begin{array}{c}101-500 \\
\text { baş }\end{array}$ & $\geq 501$ baş & & & \\
\hline \multirow{4}{*}{ Hangi yetiştirici örgütüne üye siniz? } & DKKYB & $\mathrm{n}$ & 17 & 46 & 29 & 92 & \multirow{4}{*}{6.858} & .032 \\
\hline & & $\%$ & 81.0 & 93.9 & 100.0 & 92.9 & & \\
\hline & Kooperatif & $\mathrm{n}$ & 4 & 3 & 0 & 7 & & \\
\hline & & $\%$ & 19.0 & 6.1 & .0 & 7.1 & & \\
\hline \multirow{4}{*}{$\begin{array}{l}\text { Sürünüzün verimini artırmak için } \\
\text { düzenli kayıt tutup bilimsel bir ıslah } \\
\text { (iyileştirme) yapmak ister misiniz? }\end{array}$} & Evet & $\mathrm{n}$ & 18 & 40 & 24 & 82 & \multirow{4}{*}{0.172} & .917 \\
\hline & & $\%$ & 85.7 & 81.6 & 82.8 & 82.8 & & \\
\hline & Hayır & $\mathrm{n}$ & 3 & 9 & 5 & 17 & & \\
\hline & & $\%$ & 14.3 & 18.4 & 17.2 & 17.2 & & \\
\hline \multirow{5}{*}{$\begin{array}{l}\text { Hayvancılık yapmaktan memnun } \\
\text { musunuz? }\end{array}$} & Evet & $\mathrm{n}$ & 16 & 32 & 17 & 65 & \multirow{5}{*}{1.673} & .433 \\
\hline & & $\%$ & 76.2 & 65.3 & 58.6 & 65.7 & & \\
\hline & Hayır & $\mathrm{n}$ & 5 & 17 & 12 & 34 & & \\
\hline & & $\%$ & 23.8 & 34.7 & 41.4 & 34.3 & & \\
\hline & & $\%$ & 33.3 & 20.4 & 41.4 & 29.3 & & \\
\hline \multirow{6}{*}{$\begin{array}{l}\text { Otlattığınız meranın durumu sizce } \\
\text { nasıl? }\end{array}$} & Yeterli & $\mathrm{n}$ & 3 & 5 & 1 & 9 & \multirow{6}{*}{6.391} & .172 \\
\hline & & $\%$ & 14.3 & 10.0 & 3.4 & 9.0 & & \\
\hline & Yetersiz & $\mathrm{n}$ & 14 & 36 & 27 & 77 & & \\
\hline & & $\%$ & 66.7 & 72.0 & 93.1 & 77.0 & & \\
\hline & Orta derece & $\mathrm{n}$ & 4 & 9 & 1 & 14 & & \\
\hline & & $\%$ & 19.0 & 18.0 & 3.4 & 14.0 & & \\
\hline
\end{tabular}

Üreticilerin \%77'si kullandıkları meranın yetersiz, $\% 14$ 'ü orta derece ve \%9'u ise yeterli olduğunu be- lirtmiştir. İstatistiki olarak anlamsız olmasına rağmen işletme büyüklüğü arttıkça kullanılan meranın 
yetersiz olduğu düşüncesinin arttığı belirlenmiștir. Yetiştiriciler küçükbaş hayvan yetiștiriciliğinde en önemli sorunları sırası ile \%34,1'i yüksek yem maliyeti, \%33,3'ü mera yetersizliği ve \%19,4'ü ise pazarlama olarak belirtmişlerdir.

\section{Tartışma}

İşletmelerdeki ortalama koyun sayısını Paksoy ve ark. (2006) Kahramanmaraş ilinde 123 baş, Bilginturan ve Ayhan (2009) Burdur ilinde 112,8 baş ve Ceyhan ve ark. (2015) ise Niğde ilinde 327 baş olarak bildirmişlerdir. Erzincan ilindeki sürü büyüklüğü Paksoy ve ark. (2006) ile Bilginturan ve Ayhan (2009) bildirişlerinden yüksek ve Ceyhan ve ark. (2015) bildiriși ile benzer bulunmuştur. Özdemir ve ark. (2015) yaptıkları çalıșmada, üreticilerin \%95,8'inin serbest aşım ve \%3,4'ünün elde aşım yaptıklarını, Ceylan ve ark. (2015) ise yetiștiricilerin sadece \%3,1'inde elde aşım yöntemi uyguladıklarını bildirmişlerdir. Bulunan sonuçlar, Özdemir ve ark. (2015) ve Ceylan ve ark. (2015)'in buldukları sonuçlarla benzerlik arz etmektedir. Elde aşım yapan işletmelerin Halk Elinde Islah Projesi kapsamında bu yöntemi kullandıkları düşünülmektedir.

Yaptıkları çalışmalarda damızlık hayvanı kendi işletmelerinden temin etme oranını bu çalışmaya benzer olarak, Özdemir ve ark. (2015) \%96,6 ve Bilginturan ve Ayhan (2009) ise \%91,2 olarak bildirmişlerdir. Küçük işletmelerin genel olarak işletme dışından damızlık koç temin etmelerinin nedeni, yakın arabalılığın ortaya çıkardığı kusurlardan korunmak değil, küçük işletmelerin damızlık temininde ellerindeki hayvan sayısının yetersizliğinden kaynakladığı düşünülmektedir. Bilginturan (2008) ve Yıldız (2011)'in bildirişlerine benzer olarak koyun sağlmında makineli sağım oranı düşük bulunmuştur.

Yıldız (2011) Van ilinde yaptığı çalışmada, yetiştiricilerin \%26,2'sinin 0-300g, \%61,3'ünün 300-600g, $\% 9,5^{\prime}$ inin $600-1000 \mathrm{~g}$ ve $\% 0,6$ 'sinın ise $1000 \mathrm{~g}^{\prime} \mathrm{dan}$ daha fazla gün/baş ortalama süt aldıklarını bildirmiştir. Çalışmamızda elde edilen günlük ortalama süt verimi sonuçları Yıldız (2011)'in bildirdiği sonuçların üzerinde bulunmuştur. Çalışmamızda günlük ortalama süt verimine ait yetiştirici beyanları Akkaraman ırkı için bildirilen literatür çalışmalarının (Altın 2001) çok üzerinde bulunmuştur. Çalışmamızda üreticilerin büyük bir kısmının (\%95) sütü peynire çevirerek pazarladığı belirlenmiştir. Dönmez (2008) Bursa ilinde yaptığı çalışmada yetiştiricilerin $\% 62,5$ 'inin sütü çiğ süt olarak mandıraya verdiğini ve \%31,25'inin ise peynir yaptığını bildirmiştir. Başka bir çalışmada ise (Ceyhan ve ark. 2015) sütü, iş- letmelerin \%55,2'sinin ticari peynir yapımında kullandığını ve geri kalan ișletmelerin ise ailenin kendi ihtiyaçlarını karşılamak için yoğurt ve tereyağı gibi çeşitli ürünlere işlediğini bildirmiştir.

İşletmelerin büyük bir çoğunluğu koç katım döneminde koyunlara ek bir yemleme yapmaması, Özdemir (2015)'in bildirişi ile benzerlik göstermektedir. Halbuki koç katım döneminde dişi hayvanlara ek yemleme yapılmasının döl verimi üzerine önemli etkisinin olduğunu bildiren pek çok araştırma mevcuttur (Esenbuğa ve ark. 2001; Sezenler ve ark., 2007; Alçiçek ve Yurtman, 2009; Demiral ve İşcan, 2012).

Ceyhan ve ark. (2015) koyunculuk işletmelerinde koruyucu aşıların hepsini yaptıran işletmelerin oranını \%64,9; Karakuş ve Akkol (2013) \%30,9; Bilginturan ve Ayhan (2009) ise \%99 olarak bildirmişlerdir. Bu çalışmada elde edilen bulgular Ceyhan ve ark. (2015) ve Karakuş ve Akkol (2013) tarafından bildirilen değerlerden yüksek; Bilginturan ve Ayhan (2009) ile benzerlik göstermektedir.

Dellal ve ark. (2002) yetiştiricilerin \%7,2'sinin, Aşkın (2011) ise \%25'inin bir yetiştirici örgütüne üye olduğunu bildirmiştir. Çalışmamızda bulunan sonuçlar, Dellal ve ark. (2002) ile Aşkın (2011)'in buldukları sonuçların çok üzerindedir. Erzincan ili küçükbaş hayvan yetiştiricileri için bulunan bu örgütlenme oranı ülke ortalamasının da üzerinde olduğu düşünülmektedir.

\section{Sonuçlar}

Elde edilen sonuçlara göre Erzincan ilinde yaygın olarak yapılmakta olan koyun yetiştiriciliği daha çok süt ve süt ürünlerinin üretimini kapsamaktadır. Yetiştiriciler adaptasyon kabiliyeti ve bölgedeki diğer ırklara göre süt verimi ön plana çıkmış olan Akkaraman ırkı koyunları tercih etmektedirler.

Koyun yetiştiriciliği yapılan işletmelerde yapılan çalışma sonucu literatürde bildirilen benzer çalışmalara göre yetiştiricilerin eğitim seviyelerinin daha düşük olduğu; işletme büyüklüklerinin daha yüksek olduğu ve çalışma yapılan işletmeler içerisinde çoğunlukla yalnız koyunculuk faaliyeti yapıldığı tespit edilmiştir. İşletmelerin büyük çoğunluğu ürettikleri sütten peynir yaparak pazara sunmakta ve sürüsüne bilimsel manada ıslah yapılmasını istemektedir. $\mathrm{Bu}$ konunun politika üreticilerinin üzerinde durması gereken önemli bir konu olduğu düşünülmektedir. Damızlık koç kullanımında üreticilerin genellikle kendi hayvanlarını tercih etmeleri neticesinde yakın akrabalı yetiştiriciliğin fazla olmasından doğan 
genetik kusurları ve verim düşüklüğü konusunda çiftçinin bilinçlendirilmesi gerekmekte ve damızlık temininde yetiştirici birlikleri aktif görev almalıdırlar.

İkiz doğumlarda, düşük doğum ağırlığından ve ana sütünün yetersizliğinden kaynaklı yaşama gücü düşüklügünün yetiştiricilerin bir kısmının doğumlarda ikizlik istememelerinin ana sebepleri arasında olduğu gözlenmektedir. Özellikle büyük işletmelerde sürü yönetiminde yaşanan zorlukların ikiz doğum istenmemesinde etkili olduğu düşünülmektedir. Çalışmamızda üreticilerin bir kısmının ikiz doğum istememesinin sebeplerine inilmelidir. Gebelik döneminde plasental gelişimi güçlendirmek için besleme programlarının ve ana sütünün yetmediği durumlarda süt ikame yemi ile kuzuların beslenebileceği konusunda yetiştirici bilgilendirilmelidir.

Yetiştiricilerin büyük bir bölümü, dişi kuzuların erken yaşta damızlıkta kullanılmasını istememektedir. Uygun canlı ağırlı̆̆a ulaşmadıkları için yetiştiricilerin anaç kuzuların gebe kalmasını istemedikleri düşünülmektedir. İlkine kuzulama yaşının geç olmasının yetiştirici ve ülke ekonomisine zararları göz önüne alındığında, ilkine kuzulama yaşını düşürecek bilimsel uygulamaların (mevsim dışı kızgınlık, hormon uygulama, bakım besleme uygulamalarının iyileştirilmesi) üreticilerle paylașılması gerekmektedir.

Ortalama süt verimine dair yetiștirici beyanları literatür bildirişlerinden yüksek bulunmuştur. Fakat bölgede Akkaraman koyun yetiştiriciliğinin süt verimi yönünde yapıldığı unutulmamalıdır. Sahada Akkaraman ırkı koyunlarının süt verim özelliklerini ortaya koyacak yeni çalışmaların yapılması gerekmektedir.

Örgütlenme oranının yüksek olması, ilde küçükbaş hayvan yetiștiricilerinin Erzincan Tulum Peyniri üretimi için organize olmasına bağlanmaktadır. Çalışmamızda örgütlenme oranı belirlenmesine rağmen, örgütlenmenin fonksiyonelliği, birlikten beklentiler ve memnuniyet durumu üzerinde çalışılmamıştır. Yüksek bir örgütlenme oranına sahip Erzincan ve çevre illerindeki küçükbaş yetiștiriciliğinde, üreticilerin örgütlenmesi üzerine ayrı bir çalışma yapılmasının gerektiği düşünülmektedir.

\section{Kaynaklar}

Akçapınar, H., 1994. Koyun Yetiştiriciliği. Medisan Yayın Serisi. No:8, Ankara, 123 pp.
Alçiçek, A., Yurtman, Y., 2009. Entansif Koyunculukta Besleme. Uludağ Üniversitesi Ziraat Fakültesi Dergisi, 23(2): 1-13.

Altın, T., 2001. Koyunlarda Süt Veriminin Laktasyon Boyunca Değişimi Ve Farklı Yöntemlere Göre Tahmin Edilmesi. Yüzüncü Yıl Üniversitesi Tarım Bilimleri Dergisi, 11(2), 1-7.

Anonim, 2018. Erzincan Valiliği. http://www.erzincan. gov.tr /cografi-yapisi. (Erişim tarihi: 27.02.2018)

Aşkın, Y., 2011. Van İli Merkez İlçede Küçükbas Hayvancılık Faaliyetleri Ve Genel Sorunlar. Yüksek Lisans Tezi, (Basılmamış), Yüzüncü Yıl Üniversitesi Fen Bilimleri Enstitüsü, Van, 75 s.

Bilginturan, S., 2008. Burdur İli Damızlık Koyun ve Keçi Yetiștiriciler Birliği Üyesi İșletmelerin Yapısal Özellikleri Ve Sorunları Üzerine Bir Araştırma. Süleyman Demirel Üniversitesi Fen Bilimleri Enstitüsü, Yüksek Lisans Tezi, (Basılmamış), Isparta, $53 \mathrm{~s}$.

Bilginturan, S., Ayhan, V., 2009. Burdur ili damızlı koyun ve keçi yetiştiriciler birliği üyesi koyunculuk işletmelerinin yapısal özellikleri ve sorunları üzerine bir araştırma. Hayvansal Üretim, 50(1): 1-8.

Ceyhan, A., Şekeroğlu, A., Ünalan, A., Çınar, M., Serbester, U., Akyol, E., Yılmaz, E., 2015. Niğde ili koyunculuk işletmelerinin yapısal özellikleri ve sorunları üzerine bir araştırma. Kahramanmaraş Sütçü İmam Üniversitesi Doğa Bilimleri Dergisi, 18(2), 60-68.

Çetinkaya, K., 1982. İzmir, Aydın ve Manisa illerindeki koyunculuğun yapısal ve çevresel özellikleri içinde döl verimi durumu. Lalahan Zootekni Araştırma Enstitüsü, Yayın No:64.113 s.

Çiçek, A., Erkan, O., 1996. Tarım Ekonomisinde Araștırma Ve Örnekleme Yöntemleri. Gaziosmanpaşa Üniversitesi Ziraat Fakültesi Yayınları No: 12. Ders Notları Serisi No: 6. Tokat, $185 \mathrm{pp}$.

Dellal, G., Eliçin, A., Tekel, N. ve Dellal, İ., 2002. GAP bölgesinde küçükbaş hayvan yetiştiriciliğinin yapısal özellikleri. Proje Raporu 2002-1, Yayın No: 82. Ankara.

Demiral, K., İşcan, K. M., 2012. Akkaraman ırkı koyunlarda flushing uygulamasının döl verimi özelliklerine etkisi. Erciyes Üniversitesi Veterinerlik Fakültesi Dergisi, 9(1), 23-28.

Dönmez, O., 2008. Bursa İli Koyunculuk İşletmelerinin Yetiștiricilik Açısından Yapısı. Namık Kemal Üniversitesi Fen Bilimleri Enstitüsü Yüksek Lisans Tezi, Tekirdağ, 51 sayfa.

Esenbuğa, N., Macit, M., Karaoğlu, M. ve Dayığlu, H., 2001. Ek konsantre yemle beslenen İvesi ve Morkaraman ırkı kuzuların erken yaşta damızlıkta kullanılma 
olanakları üzerine bir araştırma. Atatürk Üniversitesi Ziraat Fakültesi Dergisi, 32(2), 157-162.

Gezer, O., 2010. Sivas İli Koyunculuk İșletmelerinin Yapısal Özellikleri. Selçuk Üniversitesi Fen Bilimleri Enstitüsü, Yüksek Lisans Tezi, (Basılmamış), Konya. 75 s.

Karakuș, F., Akkol, S., 2013. Van ili küçükbaș hayvancıllk işletmelerinin mevcut durumu ve verimliliği etkileyen sorunların tespiti üzerine bir araştırma. Yüzüncü Yıl Üniversitesi Fen Bilimleri Enstitüsü Dergisi, (Basılmamış), Van, 18(1-2), 9-16.

Kaymakçı, M. 2013. İleri Koyun Yetiştiriciliği. Genişletilmiş 4. Baskı, Bornova, İzmir, 370 pp.

Kaymakçı, M., Özder, M., Karaca, O., Torun, O., Baş, S., Koşum, N., 2009. Türkiye Koyun Islah Stratejisi. Türkiye Koyunculuk Kongresi, Ege Ünversitesi Ziraat Fakültesi Zootekni Bölümü Bildiriler Kitabı. s:2534.

Özdemir, G., Daş, A., Nursoy, H., Ildiz, S., 2015. Bingöl İli küçükbaş hayvan yetiştiriciliği koç/teke katım dönemi uygulamalarının değerlendirilmesi, 26(1), 13-16.

Paksoy, S., Atılgan, A., Akyüz, A., Kumova, Y., 2006. Kahramanmaraş yöresi koyunculuk işletmelerinin yapısal yönden mevcut durumları ve geliştirilmesi üze- rine bir araştırma. Süleyman Demirel Üniversitesi Ziraat Fakültesi Dergisi, 1 (2): 17-27.

Sezenler, T., Köycü, E., Özder, M., Karadağ, O., Erdoğan, İ., 2007. Karacabey merinosu koyunlarında yaş ve vücut kondüsyon puanının kimi döl verim özelliklerine etkisi. Tekirdağ Ziraat Fakültesi Dergisi, 4(3), 277-281.

Tekinşen, K. K., Akar, D., 2017. Erzincan Tulum Peyniri. Atatürk Üniversitesi Veterinerlik Bilimleri Dergisi, 12(2): 218-226.

TUIKK, 2018. Küçükbaş Hayvancılık Verileri. Türkiye İstatistik Kurumu (www.tuik.gov.tr), (Erişim tarihi: 27.02.2018).

Türkyılmaz, D., 2014. Atatürk Üniversitesi Ziraat İșletmesinde Yetiştirilen Saf Morkaraman Ve Romanov X Morkaraman Melez Kuzuların Döl Verimi, BüyümeGelişme ve Kesim Karkas Özelliklerinin Belirlenmesi. Atatürk Üniversitesi Fen Bilimleri Enstitüsü Zootekni Anabilim Dalı, (Basılmamış), Erzurum, 80 pp.

Yıldız, A., 2011. Van İli Merkez İlçede Küçükbaş Hayvancılık Faaliyetleri ve Genel Sorunlar. Yüzüncü Yıl Üniversitesi Fen Bilimleri Enstitüsü Yüksek Lisans Tezi, Van. 63 pp.

Yazıcıoğlu, E., Erdoğan, S., 2004. SPSS Uygulamalı Bilimsel Araştırma Yöntemleri. Detay Anatolia Akademik Yayıncllık. 1. Baskı. Ankara, 443 pp. 